\author{
DOI 10.31558/2519-2949.2019.4.12 \\ УДК [327.8+008]-043.96
}

ORCID ID: https://orcid.org/0000-0003-3361-8838

Кушнарьова М. Б., Національна бібліотека Украӥни ім. В. І. Вернадського

\title{
ВІДРОДЖЕННЯ/РЕНЕСАНС: ІСТОРІЯ ЗАСТОСУВАННЯ КУЛЬТУРОЛОГІЧНОГО КОНЦЕПТУ В ПОЛІТИЧНІЙ ПРАКТИЦІ
}

\begin{abstract}
Стаття присвячена аналізу досвіду застосування культурологічного поняття «ренесанс/відродження» у політологічній сфері.

Наголошується, щчо історія широкого застосування концепта відродження у гуманітарному та суспільному знанні розпочалася у другій половині XIX cm.. Застосування згаданого концепту по тому набуло вкрай широкого як географічного, так і галузевого ареалу, і тепер він є звичним елементом не тільки мистецтвознавчих та історичних, а й економічних, політологічних, соиіальних студій та державотворчої діяльності.

Виокремлено світоглядний, політологічний та історіософський чинники набуття концептом відродження такої значної популярності.

Випадки суто інструментального застосування концепту розглядаються на прикладах гасел, щзо їх політичні діячі використовували у передвиборчих перегонах, які мали місие у США та Росії наприкінці ХХ - на початку ХХІ cm. (Р.Рейган, Б.Клінтон, Д.Трамп, Б.Сльиин, В.Путін).

Як досвід конщептуального застосування ідеї відродження наведено приклади, пов'язані з добою Б.Муссоліні, діяльністю графа С.Уварова у Росії (І половина ХІХ ст..), як приклад непрограмного відродження - українське національне відродження XIX cm. .

Як конщепт, так і похідна від нього ідея відродження наділені певною ефектністю, привабливістю для профанних кіл суспільства, що істотно полегшує їхн використання різноманітними політичними силами. Конщепт та ідея постають як украй невизначені, позбавлені як чітких меж, так і можливостей до моделювання, такі, щьо важко надаються до свідомого цілепокладання, отже, спроба їхньої реалізації провокує до більш-менш очевидного порушення причинно-наслідкових зв 'язків, щз визначають поступальний характер історичного прочесу. Тому суттєво конструктивнішим видається прагнення до руху у майбутнє, без закликів до повернення у минуле, яким би яскравим воно не здавалося.
\end{abstract}

Ключові слова: відродження, Росія, США, Украӥна, Італія, президентські вибори.

Концепт відродження характеризується високим ступенем полісемантичності та, відповідно, дуже розмитими межами. Навіть поверховий аналіз численних прикладів його використання дозволяє виокремити випадки застосування «відродження» у значенні «відновлення», «оновлення», «воскресіння», «відбудова» тощо, а це, своєю чергою, уможливлює застосування цього концепту не лише у культурній, а й у соціальній, економічній, державотворчій сферах.

Слово «відродження», насамперед у варіанті «ренесанс», набуло великої популярності у другій половині XIX ст. Потужним імпульсом до цього процесу в середині XIX ст. стали лекції та праці Жуль Мішле, в яких він уперше застосував слово «Ренесанс» до культурної доби, що згодом увійде до історії світової культури під цією назвою, а також - поява у 1860 р. праці Якоба Буркгардта «Культура Італії у добу Ренесансу».

За надзвичайно тонким, хоча й не позбавленим дискусійності зауваженням П.М.Біциллі, світогляд людей, котрі «відкрили Відродження», тобто Мішле, Буркгардта і Ніцше, «хоч i романтичний, за інтуіцією, що лежала в його основі, проте за своїм змістом, за ідеологією, був ворожий романтизмові» $[1$, с.62]. Ця двоїстість відбилася на тому образі Ренесансу, який вони поширили світом, адже вони, як і всі інші дослідники, побачили у об'єкті свого дослідження, тобто у періоді існування європейської культури, що тривав приблизно з XIV по XVI ст., те, що хотіли побачити. Властива саме романтичному світогляду контроверсійність передбачала звернення до опозицій, застосування методу визначення через протиставлення як засобу створення картини світу, що можна вважати своєрідним прикладом прояву апофатичної традиції в реаліях нового часу. 
Мішле та Буркгардт, за Біциллі, «підносили Ренесанс коштом середньовіччя». Внаслідок цього середньовіччя ставало набагато похмурішим і сумнішим, а Ренесанс, відповідно, - набагато веселішим і світлішим.

Друга половина XIX століття, особливо його кінець, та початок XX-го, була добою, сприятливою для наукового прогресу у всіх галузях знання. Тодішне суспільство із захватом вітало найрізноманітніші новації, тому доба Ренесансу, як уособлення прагнення до стрімкого руху вперед шляхом заперечення нещодавнього минулого, як час великих літературних і мистецьких здобутків, стала просто популярною. Так само популярним стало й слово, що ії позначало. Ім'я власне стало ім'ям загальним, поступово перетворилося на концепт.

Шлейф конотацій поняття 3 плином часу став настільки вражаючим, що у подальшому дослідникам - культурологам, історикам, мистецтвознавцям, навіть політологам - було важко впоратися зі спокусою відкрити ще якийсь «ренесанс», позначаючи його словом, що починалося якщо не з великої літери, то хоча би з прописної. Тож не дивно, що кількість ренесансів стрімко зростала і тепер ми поінформовані, що, крім знаного європейського, про який писав Буркгардт, були, наприклад, ще каролінгський ренесанс, англосаксонський, оттонівський, арабський, китайський, візантійський палеологівський, грузинський, православний, російський тощо. 3 плином часу також з'явилася велика кількість випадків, коли певне мистецьке, культурне чи соціально-політичне явище, яке $\epsilon$ хронологічно та географічно вужчим, аніж вищезгадані, позначається словом, що у відповідній національній мові $\epsilon$ аналогом «ренесансу», але не містить притаманного початковому терміну французького забарвлення, перетворюючись на «відродження» («українське відродження», «слов’янське відродження», «возрождение русской духовности»). Відтоді постійно лунають заклики до відродження певної країни або явища. Кількість подібних прикладів $є$ неозорою, їх можна знайти у культурній та політичній спадщині багатьох етнічних чи державних утворень.

Настільки високу популярність зумовили кілька чинників.

Найпотужнішим з них видається світоглядний. Не буде перебільшенням стверджувати, що популярність концепту відродження має виразні світоглядні корені: уможливлюючи повернення, відновлення, повторення, він створює в людини ілюзію подолання лінійності власного існування. Лінійність у певному сенсі є безжальною та жорстокою, вона не залишає права на помилку, отже провокує песимістичні думки. Циклічність, що дозволяє переробити, виправити, позбутися помилок, «почати спочатку», насправді $\epsilon$ комфортнішою за лінійність. Окрім того, лінійність виключає повернення, тобто можливість побачити чи пережити щось іще раз, а така перспектива «one way ticket» теж $є$ доволі сумною. Навколишнє середовище теж налаштовує людину саме на циклічність, тому не дивно, що наші пращури спочатку бачили світ саме в такий спосіб, адже циклічність вкорінена у прадавньому бутті як основа архаїчного світорозуміння. Лінійність, що заперечує повернення, $є$ пізнішим винаходом людства. 3 огляду на це, концепт відродження можна трактувати як прояв циклічного світосприйняття у добу панування лінійного.

Однією з рис згаданого архаїчного світогляду $є$ стійка схильність людини до мислення опозиціями. Світ, що його осмислюють у такий спосіб, стає суттєво простішим і зрозумілішим. Коли циклічне бачення існування світу поєднується із лінійним, то мислення опозиціями формує уявлення, що відповідає послідовності, за якої певний період «минулого» асоціюється 3 «розвитком», «розквітом», «піднесенням», «славою», «могутністю», назагал - з усім хорошим, позначеним знаком «плюс». Відповідно до уявлення про лінійність історичного процесу, теперішній період стає уособленням «занепаду», «забуття», «безсилля», загалом - неприємного та поганого, тобто, усього зі знаком «мінус». Внаслідок уявлення про циклічність бажаним є повернення у майбутньому до «хорошого», тобто до минулого, ознаками якого будуть ті самі позитивні характеристики, й воно так само позначатиметься знаком «плюс».

Через це, сама ідею повернення постає як принадна, бажана та реалістична, оскільки виглядає природною і закономірною. Отже, це повернення має відбутися мало не само собою. Це, своєю чергою, кличе до життя стійкий образ помаху чарівної палички або зненацька відчинених дверей, внаслідок чого все миттєво змінюється, занепад припиняється, розвиток починається, всі бідні стають багатими, а всі сумні - веселими. Якщо рухатися в цій системі координат, то виходить, що для того, аби життя змінилося на краще, не потрібно довго й тяжко працювати, думати, переробляти, напружуватися і взагалі чекати, оскільки все може статися швидко і яскраво, в один момент, причому, знову-таки, само собою. 
Наступним чинником є психологічний. Концепт відродження, завдяки імпліцитній присутності в ньому мотиву повернення, покликаний допомогти розв'язати психологічні проблеми, пов'язані 3 певною модифікацією комплексу неповноцінності, що проявляється як у психіці однієї людини, так і в колективній свідомості певної спільноти. Цю модифікацію можна умовно позначити як «комплекс колишніх успіхів». Як писав свого часу засновник вивчення психологічних комплексів Альфред Адлер, «минуле вказує на характер неповноцінності чи неадекватності, яку ми намагаємося подолати» [2, с.57]. Відтак, колективні спогади про колишні успіхи справляють неприємне враження через те, що здібності, нібито підтверджені колишніми досягненнями, не відповідають теперішньому стану речей.

Часто це вважають атрибутом т.зв. комплексу малих народів. Зокрема, сучасний російський експерт М.Саморуков відтворює в іронічному ключі уявний дискурс уявної країни, покликаний до життя таким комплексом: «Ви думаєте, наша країна з'явилася лише пару десятиліть тому, - та нічого подібного. (...) ми були тут раніше за всіх. Квітли, завойовували, кріпили державу. Потім через зрадництво друзів та підлість ворогів - виникли непорозуміння, але тепер усе залагоджено» [3]. Автор констатує прояви цього комплексу в сучасній Росії та дивується, звідки вони взялися, адже Росія - країна з давньою історією: «Росія навіщось запозичує комплекси малих народів, хоча в неї немає для їхньої появи ніяких історичних підстав. Хіба у росіян $є$ якась необхідність доводити, що їхня державність виникла не вчора, а існує вже багато століть?» [3]. Подібну нелогічність теж можна вважати додатковим аргументом на користь актуальності чіткішого визначення явища, про яке йдеться: справа не в «малих народах», а у колишніх успіхах та спричинених ними колишньому впливі, колишній могутності, а ще - убажанні, ревіталізувавши колишні досягнення, довести всім, що «мы все можем повторить». Колишні успіхи були не тільки у малих, а також у великих народів. Ба більше, великі народи, ймовірно, болісніше сприймають спогади про такі успіхи.

Тому концепт відродження й зберігає стійку популярність - він відповідає більш або менш прихованим прагненням широкого суспільного загалу.

Окрім того, істотну роль у тому, що концепт відродження задіяний у найрізноманітніших сферах суспільної свідомості, відіграв історіософський чинник. Загальновідомо, що більшість людей, не зайнятих безпосередньо дослідженням конкретних історичних періодів, намагаючись вибудувати у своїй уяві картину світової історії, оперують стереотипами. Стереотип є наслідком міфологізації, об'єктом якої тією чи іншою мірою стає кожна історична доба. Доба європейського Ренесансу в цьому розумінні зазнала не просто міфологізації, а сакралізації (М.В.Алпатов). Це особливо слушно щодо радянського періоду, позаяк дозволяло позиціонувати радянське суспільство як ідейного спадкоємця ренесансних гуманістів та всієї тогочасної культури.

За влучною і дотепною думкою Л.М.Баткіна, «гуманістична ідея» відродження досить швидко вбралася у «фразеологічні шати», внаслідок чого Ренесанс як епоха і в наші дні продовжує асоціюватися з протиставленням «середньовіччя (темне, похмуре, людина забита, нещасна, науки не було, освіта і мистецтво - винятково церковні, отже, недолугі) - Ренесанс (світлий, веселий, людина вільна, розкута, щаслива, розквіт науки, освіти і мистецтва, навколо - суцільні генії)». I хоча наукові середовища вже давно відмовилися від такого спрощеного потрактування двох складних епох, у масовій свідомості, якраз внаслідок цього спрощення, воно продовжує свою впевнену ходу. I хоча середньовіччя, судячи зі світової популярності кіно- й телепродукції на кшталт «Володаря перснів», «Гри престолів», теж, принаймні, у масовій свідомості, переживає якесь своєрідне відродження, широкий загал продовжує вважати, що Ренесанс - це вершина розвитку думки та мистецтва. Доказом на користь цього твердження є хоча би перетворення «Джоконди» та її автора на героїв популярної культури, нещодавня метушня навколо продажу «Спасителя»* та ін. Отже, і в наш час доба Відродження/Ренесансу продовжує залишатися загальновизнаним символом розквіту, творчого злету, піднесення. Це переноситься і на концепт відродження як такий.

Зазначені чинники уможливлюють використання концепту відродження політичними силами, котрі, маючи перед собою різні цілі, прагнуть впливати на широкий загал. Способи використання концепту та похідної від нього ідеї відродження можна умовно поділити на інструментальні та концептуальні.

Як приклад суто інструментального використання можна навести заклик «знову зробити Америку великою», який тричі упродовж неповних сорока років (!) мав переконливий успіх у виборців США. Це гасло вперше використав у своїй передвиборчій кампанії у 1979 році Рональд Рейган у вигляді «Let's make America great again» (Давайте зробимо Америку великою знову); потім 
у 1992 році - Білл Клінтон («We'll make America great again»- Ми зробимо Америку великою знову). Отже, Трамп, з його «Make America great again», був третім, хто використав варіант того самого гасла**. Нібито невелика різниця у гаслах трьох майбутніх президентів, - пропозиція-заклик (за Рейганом), констатація майбутнього (за Клінтоном), наказ (за Трампом), - насправді $\epsilon$ концептуальною, як з огляду на політику та особистості Рейгана, Клінтона і Трампа, так і з огляду на шлях, який пройшло американське суспільство за останні сорок років. Той факт, що упродовж цього періоду в США у президентських перегонах тричі перемагали кандидати, які непрямо використовували риторику «відродження», свідчить про ступінь затребуваності їі американським суспільством.

Але постає питання: що мають на увазі американці, мріючи про «great again»? Час Вашингтона? Час Лінкольна? Час Ейзенхауера? Що у розумінні американців означає great стосовно їхньої держави? Очевидно, що часи великих зрушень зазвичай не вирізняються істотним підвищенням життєвого рівня населення. Але, коли припустити, що йдеться про добу діяльності Джорджа Вашингтона, то чи не означає це, що потрібно ще раз створити США?

Власне, будь-яке використання будь-якого концепту у вигляді гасла можна вважати прикладом виконання ним інструментальної функції, але, у певних випадках, це тягне за собою відповідну ідею. Зокрема, чітка артикуляція прагнень до відродження країни характерна також i для нещодавнього минулого й теперішнього Росії. Зокрема, з пророцтвом відродження Росії йшов на президентські вибори 1991 року Борис Сльцин («Россия обязательно возродится!») [4]. Менше ніж за десять років В.Путін висунув гасло, в якому мотив відродження був невербалізованим, але постулювалася обов'язковість явища, ним позначеного, а держава перетворювалася на слухняну виконавицю чийогось присуду: «Россия должна вновь стать великой державой» [4]. Як у відомій приказці: «Хіба хочеш? Мусиш». Також не можна залишити поза увагою вживання в останньому випадку саме слова «держава», а не «страна» чи «государство».

Теперішній стан речей дозволяє констатувати, що до відродження Росії продовжують невтомно закликати найрізноманітніші політичні сили («Партия возрождения России»), окремі політики й публічні особи, ЗМІ, причому настільки ревно, що навіть самі росіяни вже констатують: «Слова о возрождении России повторяются так часто, что уже потеряли свою свежесть, но не актуальность»*** [5]. Останнє уточнення красномовно свідчить, що настільки потрібне відродження усе ще не відбулося.

Утім, як і у випадку США, постає питання: яку країну в підсумку бажали би отримати внаслідок реалізації відродження претенденти на посаду президента Росії: Росію доби Петра I чи Катерини II, чи, чого не буває, Івана Грозного? А може, час Олексія Михайловича, виходячи з непохитної любові певного сегменту російського суспільства до дому Романових?

Досвід невтомного прагнення до свого відродження двох таких великих держав, як США та Росія, актуалізує питання критеріїв досягнення омріяної мети, тобто, за якими ознаками чи показниками громадяни цих країн та міжнародна спільнота зможуть визначити, що відродження відбулося, мету досягнуто, усі можуть нарешті зітхнути з полегшенням і заспокоїтись? Як відомо, шлях до досконалості $€$ нескінченним, ті, хто ним прямують, можуть настільки сповнитися пафосу великих завдань та причетності до їх реалізації, що не зважатимуть на побутові незручності на кшталт інфляції, зростання цін, падіння рівня життя тощо. Власне, саме оця здатність провокувати абсолютно щире і віддане - 3 боку «населення» - нехтування матеріальними та соціальними негараздами задля досягнення високої мети відродження держави причаровує політичні сили. Щоправда, є небезпека, що великі завдання «потеряют свою свежесть», але це вже дрібниці, з якими, за наявності бажання та замовлення, можуть впоратися досвідчені політтехнологи.

Питання про те, що саме є об’єктом відродження, не $є$ штучним, а відповідь на нього насправді дати важко. Це питання ставив, зокрема, Білл Клінтон під час виступу в рамках передвиборчої кампанії Гілларі Клінтон у 2016 р., критикуючи наведене вище гасло Трампа. Він запропонував виборцям відповісти на питання, що саме це гасло має на увазі, й запропонував свою відповідь: «Це означає, що я дам вам ту економіку, яка була 50 років тому, і поверну вас на той соціальний полюс, де були ви і багато інших людей» [6], маючи на увазі расову дискримінацію, притаманну американській реальності 1950-1960-х років, коли США за своїми економічними показниками претендували на статус наддержави. У такий спосіб Клінтон демонструє своєрідну тимчасову амнезію, одразу зауважену журналістами [6], адже він «забув», що сам використовував модифікацію згаданого гасла 24 роки тому. Водночас він цілком слушно намагається заохотити співгромадян під 
час оцінювання явищ соціально-політичного та культурного життя послуговуватися системним мисленням. Це означає, що певні досягнення слід розглядати з огляду на цілий комплекс характеристик життя країни у певний час, тобто, усвідомлюючи значення того підгрунтя, що уможливило появу попередніх досягнень.

Запорукою невдачі у реалізації ідеї відродження є те, що мрії широкого загалу про більш або менш міфічне відродження позбавлені системності, оскільки вони передбачають відродження, тобто повернення до життя, не економічних, культурних чи політичних устроїв (моделей), притаманних певній державі (народу, нації) на якомусь етапі, а сили, впливовості, могутності тієї самої держави (народу, нації), що були наслідком дії згаданих устроїв (моделей), позбавляючи наслідки причин, порушуючи елементарні логічні правила та поступальний характер історичного процесу. Це свідчить насамперед про профанний рівень мислення або про свідоме потурання певних політичних сил цьому профанному рівню, з огляду на специфіку мети, яку ці сили ставлять перед собою.

Ідею відродження застосовували також на концептуальному рівні, як модель для побудови певної форми суспільства, економіки чи держави, намагаючись відтворити явище, котре іiі спричинило. Серед поодиноких винятків можна навести програмну спробу режиму Муссоліні відродити масштабне ремісниче виробництво в Італії у 30-х рр. XX ст. Основою цього було переконання, висловлене одним із найвпливовіших тодішніх італійських журналістів Паоло Орано: «Ера Данте і Джотто була золотою добою як для ремісників, так і для Італії» [7, с.81]. Отже, на думку Орано, новий справжній розквіт Італії був можливий за умови розквіту ремісничого виробництва, а також пов'язаних із ним форм корпоративної організації, тобто характерних для італійської ренесансної дійсності цехів, братств тощо. I хоча запорукою могутності італійських земель та розквіту мистецтв у добу Відродження був не лише розвиток ремесел, а й ціла низка інших чинників, частка ремісничого виробництва італійських міст, зумовлена масштабами та рівнем його організації, у формуванні тодішнього реноме Італії як своєрідного авангарду, є значною.

Автори ідеї реанімування ремісничого виробництва в Італії брали до уваги об'єктивні риси італійської дійсності та своєрідну ригідність, притаманну суспільству, зокрема - ефективність певних суспільних моделей та світоглядних рис, що існують із доби пізнього середньовіччя і досі залишаються актуальними в Італії: відсутність потреби у сильній централізованій владі, яскраво виражений міський поліцентризм, міцність родинних та сусідських зв'язків, потужна і дієва «мораль села», велика увага до естетичних характеристик продукції [8, с.20-24]. У 20-ті рр. XX ст. це все набуло нового значення, з огляду на явище, відсутнє у часи як середньовіччя, так і Ренесансу культурний туризм, який формував особливості попиту, відтак і ринку.

Для реалізації цього завдання уряд Муссоліні розробив і втілив низку різноманітних заходів: від організації ремісничих шкіл - до проведення ярмарків та виставок [7, с.82-83]. Вочевидь, це виглядало дуже зворушливо, хоча й дещо своєрідно для доби, коли в Турині вже щосили працював FIAT. Ясна річ, ремісниче виробництво для повноцінного функціонування потребує контексту 500-річної давнини, тому, здавалося б, у реаліях ХХ століття воно може бути хіба що декоративним або, у кращому випадку, - нішевим елементом. Але до сьогодні в економіці Італії, на відміну від інших європейських країн, частка малого бізнесу, який працює здебільшого у сегменті виробництва харчових продуктів, меблів, споживчих товарів, сувенірів, є доволі значною. До прикладу, у 2015 році підприємства, на яких працювало менше 10 людей, становили 95,3\% від загальної кількості підприємств, на них працювало 46,8\% усіх працевлаштованих італійців [9].

Прикладом концептуального застосування ідеї відродження можна вважати спробу відновлення, точніше, ревіталізації в сучасній Росії сили трьох хрестоматійних засад, запропонованих у першій половині XIX ст. міністром народної просвіти графом С.Уваровим: православ'я, самодержавності й народності. Сумнозвісне нині слово «скрепы» - це, за великим рахунком, ті самі уваровські «три начала», більш або менш модернізовані й припасовані до контексту Росії початку XXI ст. для кожного окремого «начала». Особа графа С.Уварова в сучасному російському громадськополітичному дискурсі не акцентується, можливо, тому що ставлення громадськості до буквального повернення на двісті років назад може бути неоднозначним. Утім, спорідненість «скреп» і згаданої тріади є очевидною.

3 огляду на тривалість існування його ідей (майже двісті років!) граф Сергій Уваров може претендувати на посаду головного генія Росії. Це припущення позбавлене іронічності, адже запропонована цим діячем у першій половині XIX ст. тріада не лише не втратила сили, а, навпаки, як переконливо доводить сучасна російська дійсність, є напрочуд життєздатною. Почасти тому, що вона характеризується цілком постмодерністською множинністю смислів, надаючись 
до найрізноманітніших інтерпретацій: у той чи інший спосіб нею користувалися дуже різні російські правителі, котрі переслідували дуже різні цілі.

Безумовно, Уваров не сам вигадав свою тріаду. Ключовий їі елемент, тобто народність, був на той час у фокусі уваги інтелектуалів і митців різних країн Європи, насамперед Британії і Німеччини. У першій половині XIX ст. народність стала об'єктом уваги фольклористів, лінгвістів, істориків, літераторів, зокрема, великий вплив мала праця Й.-Г.Гердера «Ідеї до філософії історії людства». Тож Уваров просто дуже ефективно використав досягнення передової на той час європейської думки.

Далекоглядність С.Уварова проявилася насамперед у тому, що йому взагалі не йшлося про відродження. У 1833 році він обстоював перед Миколою I значення своєї знаменитої тріади винятково заради порятунку держави: «В сих священных остатках ее [России, - М.К.] народности находится и весь залог будущего ее жребия. Правительству (...) принадлежит собрать их в одно целое и связать ими якорь нашего спасения» $[10$, с.70]. Ба більше, Уваров демонструє заперечення самої ідеї відродження як такого, оскільки воно передбачає рух назад: «Народность не состоит в том, чтобы итти назад или останавливаться; она не требует неподвижности в идеях» [10, с.71]. Уваров виступав за розвиток, хоча й робив це вимушено, визнаючи його невідворотність: «...европейские идеи, без коих мы не можем уже обойтись, без искусного обуздания их грозят нам неминуемой гибелью» $[10$, с.70].

Інтенція «рятувати», котра опосередковано свідчить про наявність небезпеки загибелі, безумовно, не могла стати популярною. Через те, очікувано, у пізнішій російській громадській думці вона поступилася місцем ідеї «відродження», що проявилася у виникненні, зокрема, такого явища як «русский ренессанс» на початку XX ст.

Радянській Росії, тобто державі, котра, як вважали ії засновники, вперше в історії встановила диктатуру пролетаріату і створила СРСР під гаслом «Мы наш, мы новый мир построим», ідея відродження була чужа за визначенням. Ймовірно, відіграли свою роль також певні релігійні конотації (відродження-воскресіння), які, за умов боротьби із релігією, сприймалися як негативні. Відповідно, концепт відродження був відсутній у радянському дискурсі аж до кінця 70-х pp. XX ст. Прикметно, що навіть упродовж відбудови радянської економіки після Другої світової війни його не використовували, надаючи перевагу «відновленню» («восстановление»), саме під такою назвою «відновлення народного господарства» - період 1945-1950 pp. фігурував у навчальній та суспільнополітичній літературі.

Хай як тавтологічно це не звучить, але ознаки відродження «відродження» як суспільнополітичної ідеї вперше промайнули у 1978 році, коли побачила світ трилогія спогадів Л.І.Брєжнєва, друга книга якої називалася «Відродження» («Возрождение»). Автор (ймовірно, А.Аграновський), мабуть, виходив з того, що «відродження» викликає у реципієнтів значно вищий рівень пафосу, аніж прозаїчне «відновлення», тому в тексті він ювелірно поєднує ці два варіанти: «Закон о четвертом пятилетнем плане (1946-1950 гг.), принятый в марте 1946 года, предусматривал возрождение «Запорожстали»: «Восстановить производство тонкого холоднокатаного листа на Юге...» [11, с.6]. Текст книги містить кілька випадків вживання, хоча й не акцентованого, саме «відродження», а не «відновлення», хоча, безумовно, найбільший вплив на панівний інформаційний та культурний дискурс країни мала назва. Враховуючи особливості тодішньої політичної системи, тоталітарний характер держави і притаманні вкрай ієрархізованій верхівці (як політичній, так і культурній) традиції догоджати вищій владі, не дивно, що невдовзі з'явилися телефільми й популярні пісні, котрі тією чи іншою мірою використовували це поняття.

У 1980-ті рр. «відродження» не користувалося популярністю, оскільки неодноразові зміни курсу держави у першій половині 80-х рр. спричинили певну, якщо не ідеологічну, то тактичну нестабільність, що виключала появу якихось концептуальних пропозицій, а запропоновану М.Горбачовим «перебудову» теж складно було корелювати з «відродженням», адже очевидно, що «перебудовувати» - це одне, а «відроджувати» - це зовсім інше.

Справжній «ренесанс» концепту відродження у Росії розпочався після розвалу СРСР і він, як зазначено вище, триває досі.

Історія України позначена двома випадками застосування концепту відродження до суто української тематики. Обидва випадки позначають явища непрограмні, такі, що отримали свою назву post factum.

Першим є українське національне відродження. Якщо спробувати окреслити усталене уявлення про нього, то, відповідно до того, яке наразі можна вважати офіційним, тобто закріпленого 
у шкільній програмі з історії України, українське національне відродження тривало з кінця XVIII та упродовж першої половини XIX ст. на українських землях, що входили тоді до складу двох імперій - Австро-Угорської та Російської. Змістом цього руху було «Формування сучасної української національної самосвідомості», а центрами - на підросійській території - Харківський та Київський університети $[12$, c.57, 58]. Автори широко відомого шкільного підручника Ф.Г.Турченко та В.М.Мороко вважають, що спричинили це явище «Модернізація та національне відродження, які почалися в Західній Європі, поступово перекинулися в Україну» [13, с. 9].

У розділах, присвячених пізнішому часу, тобто другій половині XIX та початку XX ст., укладачі програми українське національне відродження вже не згадують, вживаючи словосполучення «український національний рух»****.

Таке потрактування українського національного відродження свідчить про те, що укладачі програми та автори підручника керувалися баченням М.С.Грушевського, яке він виклав у «Нарисі історії українського народу» (1906). Виходячи з того, що шкільна програма має велике значення для формування українського сучасного популярного історичного наративу, позиція Грушевського набуває додаткової ваги. Вживаючи, - ймовірно, пропонуючи, - вислів «українське національне відродження», він стверджував, що український народ мав за модель «приклад інших слов'янських народностей», а це- «допомагає йому орієнтуватись узавданнях $\mathrm{i}$ потребах національного відродження» $[14$, с.365].

У своїй праці М.Грушевський не дає визначення цього руху та навіть у досить своєрідний спосіб інтерпретує його як «рух з культурного й національного занепаду» [14, с.376]. Також учений непрямо вказує на те, що об'єктом українського відродження була Гетьманщина. Ця думка поширилася серед учасників українського руху, котрі були сучасниками Грушевського, і через десять років вона була артикульована вже дуже чітко, зокрема, В.Дорошенком, котрий, описуючи перебіг українського руху, зазначив: «Полтава і Харків розпочинають добу відродження України по упадку Гетьманщини» [15].

Українське відродження в межах Російської імперії, за М.С.Грушевським, розпочалося у другій половині XVIII ст. і тривало до сумнозвісних заборон української мови у 1863 та 1876 рр. Аналогічний рух на теренах Австро-Угорської імперії розпочався наприкінці XVIII ст. і тривав до сучасного Грушевському періоду. Хронологічні межі, запропоновані М.Грушевським, дозволяють інтерпретувати відродження, що вело родовід з Гетьманщини, не як спробу відродити певний устрій, а як намагання продовжити процес, котрий у другій половині XVIII ст. нібито спіткнувшись, впав. Тобто М.С.Грушевському йшлося не про повернення до чогось, а про відновлення поступального руху.

Також слід звернути увагу на те, що М.Грушевський вважав закінченням українського відродження на підросійських землях події 60-70-х pp. XIX ст. На сучасний погляд, бачення Грушевського виглядає дещо дивно, оскільки в зазначений час (60-70-х pp. XIX ст.) I.Франко ще перебував на початку своєї діяльності, а українське відродження без розлогої політичної діяльності Івана Франка, яка припала переважно на кінець XIX ст., нам тепер уявити складно. Одначе, на погляд Грушевського, заборони 1863 та 1876 рр. були справді катастрофами, які зробили подальше відродження, тобто розвиток українського руху на підросійській території майже неможливим. Тому він подає сучасний йому стан українства саме як наслідки катастрофи.

Також в історії України відоме «Розстріляне відродження», що позначає явище, чітко обмежене у часі (20-30-ті pp. XX ст.) і масштабах прояву, оскільки торкалося переважно царини культури. Свою назву і визначення воно теж отримало після сплину літ і свого трагічного завершення. За поширеною версією, С.Гедройць запропонував цю назву наприкінці 50-х рp. XX ст., керуючись міркуваннями про іiі виразний і промовистий характер. Назва справді $є$ вражаючою. Ймовірно, завдяки цьому, а також - ¥іі відповідності до реальних подій, які вона описує, ця назва стала невід'ємною частиною сучасного українського тезаурусу.

А от друга назва, яка, вочевидь, задумувалася як парафраз Гедройцевої, «задушене» відродження, такого успіху не мала, хоча вона позначає типологічно схоже явище, що відбувалося у 60-ті pp., i ступінь жорстокості розправи з ним влади теж у цій назві дотримана. Можливо, у сприйнятті читачів «розстріляне відродження» суто емоційно, через свою жахливість, $є$ максимально вражаючим, тому поруч 3 ним все інше тьмяніє; можливо, образ чогось «задушеного» $є$ не таким романтичним, а можливо, ще одне відродження з інтервалом у 30 років виглядає дещо несподівано.

Ясна річ, що заклики до відродження України у радянський час лунали винятково на сторінках самвидаву, а після здобуття незалежності - по всьому українському інформаційному просторі. 
Причому йдеться не тільки про відродження України, а й про відродження козацтва, козацької слави, певних народних звичаїв, окремих інституцій тощо. Прикметно, що в кожному окремому випадку конкретне відродження позиціонується як символ загального відродження України (наприклад, у твердженні президента НаУКМА Андрія Мелешевича: «У 1991 році відроджена Києво-Могилянська академія стала символом і запорукою відродження України» [16]).

Ці, загалом зрозумілі й корисні, наміри та заклики містять приховану небезпеку, яка полягає у тому, що, як і в Росії, вони можуть втратити (й поволі вже втрачають) свіжість. Окрім того, через віддаленість у часі та об'єктивні політичні умови, поступальний процес становлення модерної української ідентичності, що його мав на увазі Грушевський, упродовж останніх ста років, на жаль, поступальним не був. Тому в наші дні, на початку XXI ст., відродження Гетьманщини вже не може бути метою.

3 огляду на все сказане вище, особливої уваги заслуговує відсутність концепту відродження та відповідних «фразеологічних шат» у тексті, що з'явився кілька років тому як дороговказ для нашої держави, - «Стратегія сталого розвитку «Україна 2020». Більше того, цей документ, не перекреслюючи минулі роки існування української незалежної держави, закликає український народ просто йти уперед: «Революція гідності та боротьба за свободу України створили нову (курсив мій - М.К.) українську ідею - ідею гідності, свободи і майбутнього» (Розд.1Загальні положення) [5]. I хоча з тексту документу не зовсім зрозуміло, яку українську ідею автори вважали «старою» і що саме з нею було не так, але, з методологічної точки зору, пропонований підхід $\epsilon$ перспективнішим. Хоча, як це часто буває, на жаль, правильні заклики не завжди є запорукою релевантних наслідків.

Запропонований огляд випадків використання концепту «відродження» у політичній сфері дозволяє визначити ареал застосування і концепту, і відповідної ідеї як дуже широкий з хронологічного і з географічного погляду, а об'єкт цього відродження, стосовно кожного окремого випадку, - як невизначений. Цей об'єкт зазвичай не конкретизують, обмежуючись загальними фразами, мабуть, вважаючи, що всі розуміють, про що йдеться. Залишається погодитись зі згаданим А.Адлером, котрий стверджував: «Усі ми знаємо, що людство дуже часто задовольняється вигадками» $[2$, с.58].

Надати конструктивного характеру цій загальній невизначеності й водночас піднесеності може потрактування відродження, автором якого $є$ не надто знаний тепер Олександр Лейтес, який ще у 1925 році писав, що ренесанс «це не відродження старих форм. Це - навпаки - відродження творчих сил, що крилися довгі століття у схові і тільки тепер, за нових форм соціально-

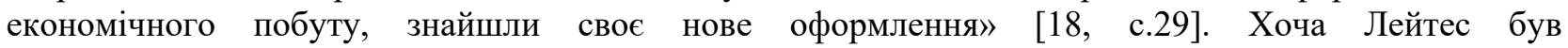
літературознавцем i мав на увазі літературний процес в Україні, його праця дає, мабуть, єдине розуміння принципу відродження, що може розв'язати своєрідну колізію, спричинену невідповідністю внутрішньої логіки поняття особливостям його застосування у сучасному світі, особливо на державному рівні. Творчі сили, безвідносно до того чи вони проявляються вони в літературі, в науці, а чи у розбудові держави, з огляду на їхню ключову роль, справді заслуговують, щоб їх відроджувати. Причому вони можуть і мають бути іншими на кожній стадії історичного процесу, що усуває необхідність «вливати нове вино у старі міхи» та убезпечує від помилок, які є неминучими при виконанні такого, загалом, неприродного завдання.

3 іншого боку, оскільки концепт «відродження» упродовж свого існування спромігся перетворитися на стереотип із чітким набором ознак, характерним для сприйняття його масовою свідомістю, то якщо вже брати на озброєння наведену думку Лейтеса, слід під час кожного випадку застосування концепту уточнювати його значення. Утім, це видається, по-перше, неможливим, подруге завдає великих збитків ефектності як концепту так і висловлювання, що його містить, а в добу політтехнологій це вкрай необачно. Тому, можливо, є сенс віддати перевагу не відродженню, тобто, опосередковано, поверненню, а простому, у певному розумінні навіть елементарному рухові вперед, як істотно ефективнішому засобу досягнення мети.

\section{Примітки:}

* Хоча, як відомо, в цій метушні авторство Леонардо да Вінчі, насправді вкрай дискусійне, зіграло суто інструментальну роль у штучному підвищенні ціни твору.

** Але Д.Трамп був першим, хто зареєстрував це гасло як торгову марку.

*** Розміщено на сайті 3.06.2018.

**** Щоправда, введено поняття «кримськотатарське національне відродження», пов’язане 3 постаттю І.Гаспринського [12, с.61] 


\section{Бібліографічний список:}

1. Бицилли П.М. Место Ренессанса в истории культуры. Сост. Б.С.Каганович. Санкт-Петербург: Мифрил. 1996. $256 \mathrm{c}$.

2. Адлер А. Наука жить. Киев: Port-Royal. 1997. 288 с.

3. Саморуков М. Большие Владимиры для малых народов: зачем ставить фэнтези-памятники персонажам из X века. URL: https://carnegie.ru/2015/07/23/ru-60839/idw9 (дата звернення: 05.07.2019)

4. Российское образование. Федеральный портал. URL: http://files.school-

collection.edu.ru/dlrstore/22364f15-607b-433e-97e6-0f71d88eeece/VuboryPrezidentatxt.pdf (дата звернення: 11.06.2019).

5. Беседин П. Как возродится Россия, если душит сама себя? URL: https://regnum.ru/news/2425302.html (дата звернення: 22.05.2019)

6. Chasmar J. Bill Clinton vowed to 'make America great again' in 1992, now says slogan is racist.

The Washington Times. URL: https://www.washingtontimes.com/news/2016/sep/9/bill-clinton-vowed-to-makeamerica-great-again-in-/ (дата звернення: 27.07.2019)

7. Lasansky M.D. The Renaissance Perfected. Architecture, Spectacle, and Tourism in Fascist Italy.

The Pennsylvania State Univ. Press. 2004. 412 p.

8. Джоунс Т. Потаємне серце Італії. Київ: Темпора. 2012. 320 с.

9. Annuario statistico italiano. URL: https:/www.istat.it/it/files//2018/12/C14.pdf (дата звернення: 20.06.2019).

10.Уваров С.С. О некоторых общих началах, могущих служить руководством при управлении Министерством Народного Просвещения. Река времен. Вып. 1. Москва: Эллис Лак - Река Времен. 1995. C. $70-72$.

11. Брежнев Л.И. Возрождение. Москва: Политиздат. 1978. 62 с.

12.Історія України. Всесвітня історія. 5-9 класи. Навчальна програма для загальноосвітніх навчальних закладів. URL: https://mon.gov.ua/ua/osvita/zagalna-serednya-osvita/navchalni-programi/navchalni-programi-5-9-klas (дата звернення: 11.08.2019)

13. Турченко Ф.Г., Мороко В.М. Історія України: підруч. для 9 кл. загальноосвіт. навч. закл. Київ: Генеза. 2017. $384 \mathrm{c}$.

14. Грушевський М С. Нарис історії українського народу. Твори : у 50 т. Редкол.: Г. Папакін, І. Гирич та ін. Т.22. Львів: Видавництво "Світ". 2015. 526 с.

15.Дорошенко В. Українство в Росії. Новійші часи. Відень. 1917. URL: http://chtyvo.org.ua/authors/ Doroshenko_Volodymyr/Ukrainstvo_v_Rosii_Novishi_chasy/ (дата звернення 02.08.2019)

16. Мелешевич А. Попереду у нас - наступні 400 років розвитку та досягнень.

URL: https://www.ukma.edu.ua/index.php/about-us/istoriya-akademiji/mohyliantsi-400-rokiv (дата звернення: 07.05.2019)

17.Стратегія сталого розвитку «Україна - 2020». URL: http://zakon0.rada.gov.ua/laws/show/5/2015 (дата звернення: 14.05.2019)

18. Лейтес А.М. Ренессанс украинской литературы. Харків. 1925. 34 с.

\section{References:}

1. Bicilli P.M. Mesto Renessansa v istorii kul'tury. Sost. B.S.Kaganovich. Sankt-Peterburg: Mifril. 1996. 256 s.

2. Adler A. Nauka zhit'. Kiev: Port-Royal. 1997. 288 s.

3. Samorukov M. Bol'shie Vladimiry dlja malyh narodov: zachem stavit' fjentezi-pamjatniki personazham iz H veka. URL: https://carnegie.ru/2015/07/23/ru-60839/idw9 (accessed: 05.07.2019).

4. Rossijskoe obrazovanie. Federal'nyj portal. URL: http://files.school-collection.edu.ru/dlrstore/22364f15-607b433e-97e6-0f71d88eeece/VuboryPrezidentatxt.pdf (accessed: 11.06.2019).

5. Besedin P. Kak vozroditsja Rossija, esli dushit sama sebja? URL: https://regnum.ru/news/2425302.html (accessed: 22.05.2019)

6. Chasmar J. Bill Clinton vowed to 'make America great again' in 1992, now says slogan is racist.

The Washington Times. URL: https://www.washingtontimes.com/news/2016/sep/9/bill-clinton-vowed-to-makeamerica-great-again-in-/ (accessed: 27.07.2019)

7. Lasansky M.D. The Renaissance Perfected. Architecture, Spectacle, and Tourism in Fascist Italy.

The Pennsylvania State Univ. Press. 2004. 412 p.

8. Dzhouns T. Potayemne serce Italiyi. Ky`yiv: Tempora. 2012. $320 \mathrm{~s}$.

9. Annuario statistico italiano. URL: https://www.istat.it/it/files//2018/12/C14.pdf (accessed: 20.06.2019).

10.Uvarov S.S. O nekotoryh obshhih nachalah, mogushhih sluzhit rukovodstvom pri upravlenii Ministerstvom Narodnogo Prosveshhenija. Reka vremen. Vyp. 1. Moskva: Jellis Lak - Reka Vremen. 1995. S. 70-72.

11.Brezhnev L.I. Vozrozhdenie. Moskva: Politizdat. 1978. 62 s.

12.Istoriya Ukrayiny`. Vsesvitnya istoriya. 5-9 klasy`. Navchal ’na programa dlya zagal’noosvitnix navchal ’ny`x zakladiv. URL: https://mon.gov.ua/ua/osvita/zagalna-serednya-osvita/navchalni-programi/navchalni-programi-5-9-klas (accessed: 11.08.2019)

13.Turchenko F.G., Moroko V.M. Istoriya Ukrayiny`: pidruch. dlya 9 kl. zagal noosvit. navch. zakl. Ky`yiv: Geneza. 2017. 384 s. 
14.Grushevs ‘ky`j M S. Nary`s istoriyi ukrayins`kogo narodu. Tvory` : u 50 t. Redkol.: G. Papakin, I. Gy`ry`ch ta in. T.22. L'viv: Vy'davny'cztvo "Svit". 2015. 526 c.

15.Doroshenko V. Ukrayinstvo v Rosiyi. Novijshi chasy`. Viden`. 1917.

URL: http://chtyvo.org.ua/authors/Doroshenko_Volodymyr/Ukrainstvo_v_Rosii_Novishi_chasy/ (accessed: 02.08.2019).

16. Meleshevy`ch A. Poperedu u nas - nastupni 400 rokiv rozvy`tku ta dosyagnen`.

URL: https://www.ukma.edu.ua/index.php/about-us/istoriya-akademiji/mohyliantsi-400-rokiv (accessed: 07.05.2019).

17.Strategiya stalogo rozvy`tku «Ukrayina - 2020». URL: http://zakon0.rada.gov.ua/laws/show/5/2015 (accessed: 14.05.2019).

18. Lejtes A.M. Renessans ukrainskoj literatury. Harkiv. 1925. 34 s.

Kushnarova M. B. Revival/renaissance: the culture studies concept in realm of political practice

The paper presents analysis of some cases of typically culture studies' notion "renaissance/revival" applying to political science.

It is accentuated, that broad applying of the mentioned concept to humanities and social studies began in the last half of the 19th century and since that time its geographical and disciplinary areal had extended exceptionally and now it could be seen as a usual element of its "native" historic and art studies, but economic, political, social researches and state-building activity as well.

Worldview, political and historiosophy are considered as the main factors that contributed to the process of the concept gaining such a popularity.

Cases of concept applying as purely instrumental means are considered using the examples of slogans proposed by political leaders in USA and Russia during the pre-election period in the end of the 20thbeginning 21 st centuries (R.Reagan, B.Clinton, D.Trump, B.Yeltsyn, V.Putin).

Examples of B.Mussolini' epoch and state activity of count S.Uvarov in Russia of the first half of the 19 th century, as non-programme revival - Ukrainian national one (19th century), are proposed as the cases of renaissance/revival conceptual applying.

The concept as well as the idea derived from it are impressive and attractive for profane society members that made possible for different political forces to use it to achieve their goals. Both concept and idea are indefinite, have no strict borders and possibilities to serve as a model and don't presuppose conscious goal-setting. It means that an attempt of its realization provokes to latent violation of causal relationship that has to provide sustainable historic development. So it looks much more constructive for modern society and political leaders to strive to build future, and do not pay attention to call back to past even if the past looks very charming.

Key words: renaissance/revival, Russia, USA, Ukraine, Italy, president elections. 